\title{
The Role of Adipose Derived Mesenchymal Stem Cells in Enhancement of Peripheral Nerve Injuries Repair
}

\author{
Ayad H. ${ }^{1}$, Zahra M. ${ }^{2}$, Gabr H. ${ }^{3}$, Ismaeil A. ${ }^{1}$, Abo Elkheir Y. ${ }^{4}$ \\ ${ }^{1}$ Plastic Surgery Department, Faculty of Medicine, Tanta University, Tanta, Egypt \\ ${ }^{2}$ Clinical Pathology Department, Faculty of Medicine, Tanta University, Tanta, Egypt \\ ${ }^{3}$ Clinical Pathology Department, Faculty of Medicine, Cairo University, Cairo, Egypt \\ ${ }^{4}$ Tissue Culture and Vaccine Department, VACSERA, Cairo, Egypt
}

Email address:

halagabr@yahoo.com (Gabr H.)

\section{To cite this article:}

Ayad H., Zahra M., Gabr H., Ismaeil A., Abo Elkheir Y.. The Role of Adipose Derived Mesenchymal Stem Cells in Enhancement of Peripheral Nerve Injuries Repair. American Journal of Bioscience and Bioengineering. Special Issue: Stem Cells for Neuro-regeneration: Where Do We Stand. Vol. 3, No. 4-1, 2015, pp. 18-23. doi: 10.11648/j.bio.s.2015030401.13

\begin{abstract}
Background: About 50\% of peripheral nerve injuries leave permenant disability. Trials to enhance nerve repair using stem cells are undergoing. Adipose derived mesenchymal stem cells (ADSCs) are good candidates for cellular-induced regeneration. Aim of the Work: The aim of the present work is to evaluate the effect of ADSCs on enhancing repair of peripheral nerve injuries. Subjects and Methods: This study was conducted on 18 patients with recent trauma involving nerve injuries at the wrist region. Patients were divided into: Group I: underwent surgical end-to-end closure GroupII: underwent surgical end-to-end closure and injection of ADSCs into the nerve sheath and surrounding tissue. Both groups were followed up using clinical assessment using Sensory Recovery Grading and Muscle Strength Grading systems in addition to electrophysiological nerve conduction tests. Results and Conclusions: This study collected a range of 1 to $2 \times 10^{6}$ ADSCs from an average of 100-150 ml fat. After 1 year, stem cell group showed significantly higher motor and sensory improvement in ulnar nerve injury; while in the median nerve injury, stem cell group showed higher motor recovery with no difference in sensory recovery.
\end{abstract}

Keywords: Peripheral Nerve, Adipose Stem Cells, Regeneration

\section{Introduction}

Peripheral nerve injuries result in persistent pain and disability in many patients (1). The peripheral nervous system (PNS) consists of 3 principle cell types: axonal, glial and supporting stromal tissue (2) With an incidence of 300,000 injuries yearly, $50 \%$ of which regain full function following treatment, new therapeutic strategies need to be introduced (3).

Following peripheral nerve injury, the neuronal cll body increases in size with dissolving of Nissl bodies and protein synthesis is initiated (4). The distal nerve end undergoes fragmentation after a few days, followed by phagocytosis of debris by local Schwann cells and macrophages(5).

After clearance of myelin debris, Schwann cells produce neurotrophic factors such as nerve growth factor and ciliary neurotrophic factor to promote growth.

Stem cell technology is one of the most promising approaches for peripheral nerve repair. As Schwann cells are responsible for nerve repair, early studies used autologous Schwann cell transplantation to improve peripheral nerve regeneration.

Mesenchymal stem cells (MSCs have shown remarkable ability for in-vitro proliferation and maturation into Schwann Cells $(6,7)$. MSCs are found in all body tissues. Traditionally, they were isolated from the bone marrow, however, they were found to be about 2500 -fold more in frequency in adipose tissue (8). Experimental studies have shown that ADSCs can differentiate into glial lineage, make them good alternative to Schwann cells in peripheral nerve repair $(9,10,11)$. ADSCs exert their regenerative function through a number of mechanisms: secretion of trophic factors (12), recruitment of endogenous Schwann cells (13), enhancing survival of sensory and motor neurons $(14,15)$, 
and possible myelin synthesis (16). These functions, combined with their easy accessibility, rapid expansion and low immunogenicity, make them ideal candidates for peripheral nerve repair (17).

This study would evaluate the role of ADSCs in enhancement of peripheral nerve injury.

\section{Subjects \& Methods}

The study was approved by the local ethical committee and informed consent is signed by every patient after explanation of procedures. The study included 18 patients admitted to Tanta hospital suffering from traumatic nerve injury at the wrist joint.

\subsection{Subjects}

\subsubsection{Inclusion Criteria}

Patients with recent trauma (less than 48 hours) of peripheral nerve injuries at the wrist region.

\subsubsection{Exclusion Criteria}
1. Polytraumatized and multiple levels of injury
2. bone fracture
3. Tendon injury (more than 3 )
4. Neuropathy

\subsubsection{Patient Groups}

Patients were divided into two groups:

Group A: included 10 patients treated by traditional method of repair with end to end anastomosis using magnification loop.

Group B. included 8 patients treated by traditional method plus injection of ADSCs to the nerve sheath and adjacent tissues.

\subsubsection{Patients were Subjected to}

1. Clinical Assessment:

a. History: Patient demographics: age sex occupation, residence and dominant hand.

b. Injury: side, site, mechanism, place, time of injury, previous injuries or disabilities and initial treatment.

c. Medical history: allergies, medications, or substance abuse.

a. Sensory testing: light touch and pin brick tests were done at the tip of the index finger for the median nerve and the tip of little finger for the ulnar nerve.

b. Motor testing: muscle strength was assessed with manual muscle strength testing according to the MRC system. For median nerve injuries the power of the thumb palmar abduction was assessed and for the ulnar nerve injuries, index and little finger abduction and little finger adduction were examined.

B. Nerve Conduction Tests:

Electrophysiological evaluation (motor and sensory nerve conduction tests) were done at 3, 6, 9 and 12 months. Parameters were compared to results of the non-involved side as internal control.

\subsection{Methods}

\subsubsection{Collection of ADSCs}

\section{(i). Harvesting}

Infiltration of the lower abdomen with normal saline with 1:50,000 epinephrine at a ratio of $1 \mathrm{ml}$ solution per millilter of aspirated tissue. Adipose tissue is then harvested using a 3$\mathrm{mm}$ diameter blunt tip cannula attached to a $60 \mathrm{ml}$ Luer-lock syringe. The aspirate was collected in sterile conical bottle.

\section{(ii). Isolation of ADSCs}

a. Washing with a sterile solution of phosphate buffered saline at equal volume three times to remove dead cells and red cells.

b. Sterile $0.075 \%$ Collagenase type I (Sigma-Aldrich) is added to the lipoaspirate for the digestive process, and incubated in a shaking incubator at $37^{\circ} \mathrm{C}$ for 30 minutes.

c. Sample was centrifuged at $600 \mathrm{xg}$ for 10 minutes, supernatatant discarded and pellet resuspended in $50 \mathrm{ml}$ of complete medium (DMEM ,10\% fetal bovine serum, 1\% antibiotic and $1 \%$ L-glutamine).

d. Red cell lysis buffer is added to eliminate red cells and sample is filtered through 100um cell strainer.

e. The filtered pellet is resuspended in complete medium.

\section{(iii). Culture}

a. Cells were counted, tested for viability using trypan blue exclusion test, and cultured in T75 tissue culture flasks in DMEM-F12 medium enriched with $10 \%$ fetal bovine serum, $1 \%$ L-glutamine and $1 \%$ penicillin-streptomycin and kept at $37^{\circ} \mathrm{C}$ in $5 \% \mathrm{CO} 2$ incubator .

b. Medium was hanged every 3-4 days and examined under inverted microscope.

c. At $75-85 \%$ confluence, cells were harvested using $2 \mathrm{ml}$ $0.1 \%$ trypsin-EDTA for 5 minutes at $37^{\circ} \mathrm{C}$. After 5 minutes 1 $\mathrm{ml}$ fetal bovine serum was added to stop the action of trypsin.

d. The cells were washed, counted and viability tested and prepared for injection.

\subsection{Surgical Intervention}

Group A: Nerve repair was performed under $3.5 \mathrm{x}$ magnifying loupes by end-to-end epineural repair using $8 / 0$ proline suture materials.

Group B: After 3 weeks from primary repair of the nere, $2 \mathrm{ml}$ of saline containing $2 \times 10^{6}$ ADSCs at the site of the nerve repair inside the nerve sheath and adjacent tissue.

\subsection{Postoperative Care}

1. Immbolization of the limb was done and physiotherapy started at the third week.

2. Tracking the regenerating axons using nerve conduction tests and Tinel's sign.

\subsection{Follow-up and Assessment of Functional Outcome}

Follow up was done using electrophysiology, clinical assessment of sensation using the British Recovery 
Grading(18). and motor recovery assessed using Muscle Strength Grading (18).

\section{Results}

This study was conducted on 18 consecutive patients suffering from traumatic nerve injury at the wrist. Demographic data of the patients is presented in Table (1).

Table (1). Demographic Data of Studied Patients.

\begin{tabular}{|c|c|c|c|c|c|c|}
\hline No & Sex & Age & $\begin{array}{l}\text { Dominant } \\
\text { Hand }\end{array}$ & $\begin{array}{l}\text { Side } \\
\text { affected }\end{array}$ & $\begin{array}{l}\text { Nerve } \\
\text { affected }\end{array}$ & Procedure \\
\hline 1 & $\mathrm{M}$ & 20 & Right & Right & Median & Conventional \\
\hline 2 & M & 33 & Right & Right & Ulnar & Conventional \\
\hline 3 & M & 28 & Right & Right & Median & Conventional \\
\hline 4 & M & 37 & Right & Left & Ulnar & $\begin{array}{l}\text { Conventional } \\
+ \text { stem cells }\end{array}$ \\
\hline 5 & M & 40 & Right & Right & Median & Conventional \\
\hline 6 & M & 35 & Right & Left & Ulnar & $\begin{array}{l}\text { Conventional } \\
\text { +stem cells }\end{array}$ \\
\hline 7 & M & 43 & Right & Right & Ulnar & Conventional \\
\hline 8 & M & 19 & Right & Right & Median & $\begin{array}{l}\text { Conventional } \\
\text { +stem cells }\end{array}$ \\
\hline 9 & M & 30 & Right & Right & Ulnar & Conventional \\
\hline 10 & M & 18 & Right & Right & Median & Conventional \\
\hline 11 & $\mathrm{~F}$ & 24 & Right & Right & Median & Conventional \\
\hline 12 & $\mathrm{~F}$ & 26 & Left & Right & Median & Conventional \\
\hline
\end{tabular}

\begin{tabular}{cccllll}
\hline No & Sex & Age & $\begin{array}{l}\text { Dominant } \\
\text { Hand }\end{array}$ & $\begin{array}{l}\text { Side } \\
\text { affected }\end{array}$ & $\begin{array}{l}\text { Nerve } \\
\text { affected }\end{array}$ & Procedure \\
\hline 13 & M & 37 & Left & Right & Ulnar & $\begin{array}{l}\text { Conventional } \\
+ \text { stem cells }\end{array}$ \\
14 & M & 41 & Right & Left & Median & $\begin{array}{l}\text { Conventional } \\
+ \text { stem cells }\end{array}$ \\
15 & M & 45 & Left & Right & Median & $\begin{array}{l}\text { Conventional } \\
+ \text { stem cells }\end{array}$ \\
16 & M & 41 & Right & Right & Ulnar & $\begin{array}{l}\text { Conventional } \\
\text { Conventional } \\
\text { + stem cells }\end{array}$ \\
17 & M & 33 & Right & Left & Median & Conventional \\
18 & M & 30 & Left & left & Median & \begin{tabular}{l} 
stem cells \\
\hline
\end{tabular}
\end{tabular}

\subsection{Results of ADSC Separation}

The present study was done on 150-250 $\mathrm{ml}$ of lipoaspirate from each patient after informed consent then processed as set in methods to yield after culture average of $2 \mathrm{X}_{10} 0^{6}$ cells (Table 2). Figure (1) shows morphology of the cultured cells

Table (2). The mean number of stem cells in lipoaspirate.

\begin{tabular}{llll}
\hline Passage & $\begin{array}{l}\text { Initial number } \\
\text { of Cells }\end{array}$ & $\begin{array}{l}\text { Cells in the } \\
\text { Confluent layer }\end{array}$ & $\begin{array}{l}\text { Culture days } \\
\text { /passage }\end{array}$ \\
\hline 1st passage & $0.20 \times 10^{6}$ & $0.85 \times 10^{6}$ & 7 days \\
2nd passage & $0.85 \times 10^{6}$ & $1.25 \times 10^{6}$ & 7 days \\
3rd passage & $1.25 \times 10^{6}$ & $2.00 \times 10^{6}$ & 6 days \\
\hline
\end{tabular}

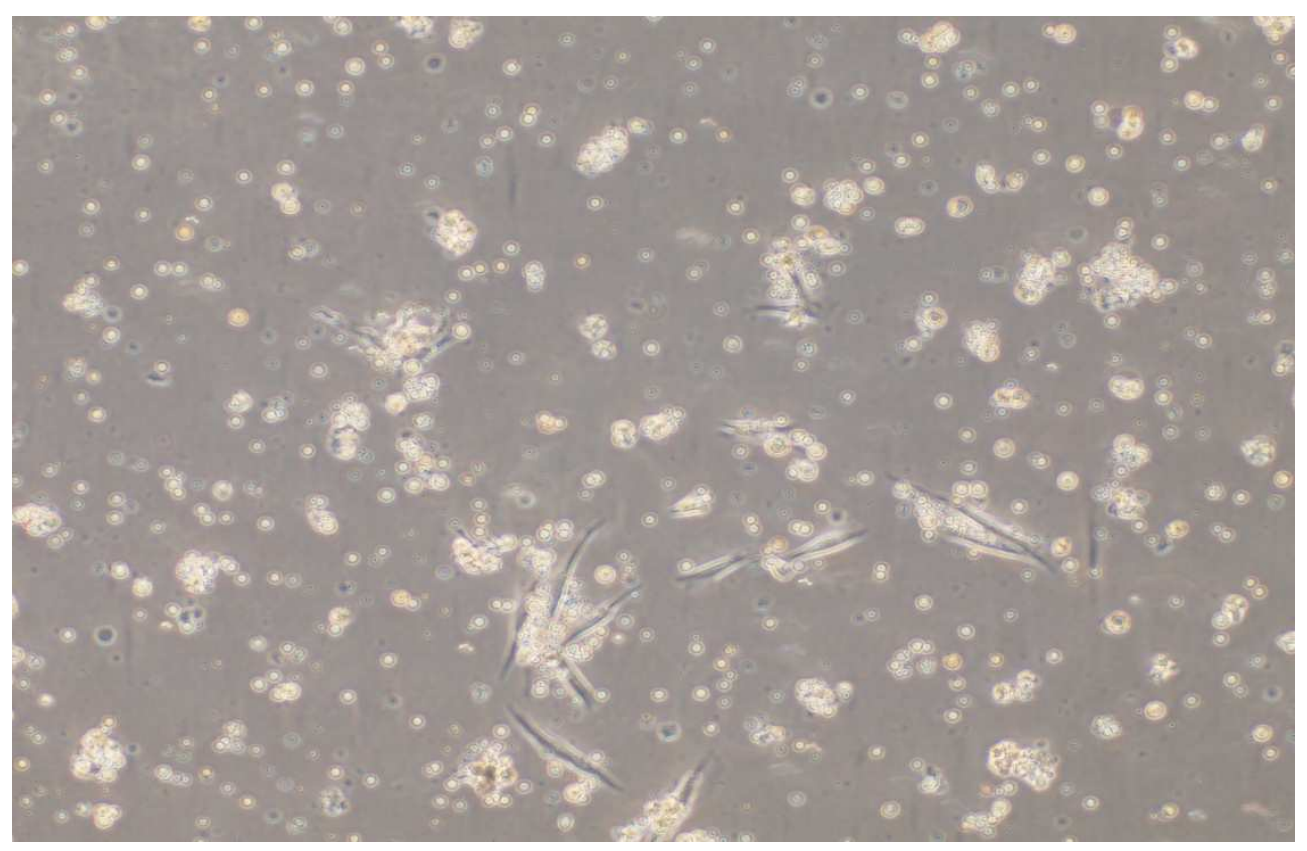

Figure (1). Morphology of ADSCS.

\subsection{Clinical Fuctional Results}

\subsubsection{Ulnar Nerve}

A. Motor assessment(based on Muscle Strength Grading)

- After 3 months :

in Group A. : 3 patients started active movement only with gravity (M2).

1 patient had trace of muscle contaction with no joint movement (M1).

in Group B. : 3 patients reached (M2) in the same period of time.

- After 6 months :

in Group A. : 1 patient can make movement against gravity but with no resistance

in Group B.: All the 3 progressing patients are in (M3)

- After 12 months:

In Group A.: 1 patient can do some independent movement (M4)

In Group B.: 1 patent in M4 and 2 patients with normal 
strength

B. Sensory assessment (based on Sensory Recovery Grading )

- After 3 months:

patients in Group A and Group B. reached to (S1) with deep cutaneous pain sensibility of the little and lateral half of the ring finger

- After 6 months:

patients in both groups reached (S2) with return of superficial cutaneous pain and tactile sensibility

- After 9 months :

2 out of four in Group A had disappearance of any previous reaction (S3) compared to 2 out of 3 in Group B

- After 12 months :

2 out of 4 in Group A had some recovery of two-point discrimination $\geq 15 \mathrm{~mm}$ compared to 2 out of 3 in Group B. $(\mathrm{S} 3+)$

\subsubsection{Median Nerve}

A)Motor assessment :

- After 3 months: all patients reached M2

- After 6 months:3 out of 6 patients of Group A (60\%) reach $\mathrm{M} 3$

4 out of 5 patients of Group B (80\%) reach M3

- after 9 months : 1 patient in Group B. reached M5

- After 12 months : $40 \%$ of Group B reached M5

B)sensory assessment:

- After 3 months : both groups reached S1

- After 6 months: both groups reached S2

- After 9 months: 4 of 6 patients of Group A reached S3

Compared to 4 of 5 in Group B

- After 12 months :3 out of 6 patients of Group A reached S3 + compared to 3 out of 5 in Group B

Electrophysiological fuctional outcome :

It's performed to determine if functional re-innervation occurred through the nerve repair and evaluate the role ADSCs after injection in the nerve sheath

\subsubsection{Ulnar Nerve}

A) Motor nerve conduction:

Along the period of $3,6,9,12$ months motor nerve conduction showed significant difference in the distal motor latency and amplitude $(\mathrm{P}<0.05)$.

Table (3). Motor nerve conduction of the ulnar nerve in both groups.

\begin{tabular}{|c|c|c|c|c|c|c|c|c|}
\hline \multicolumn{9}{|c|}{ Ulnar nerve (7 patients) } \\
\hline & \multicolumn{2}{|c|}{3 months } & \multicolumn{2}{|c|}{6 months } & \multicolumn{2}{|c|}{9 months } & \multicolumn{2}{|c|}{12 MONTHS } \\
\hline & Gp.A & GpB & GpA & GpB & GpA & GpB & GpA & GpB \\
\hline \multicolumn{9}{|l|}{ (MEAN) } \\
\hline DML(ms) & 7.3 & 6.8 & 6.625 & 5.83 & 5.35 & 4.48 & 4.375 & 3.77 \\
\hline Amplit.(mv) & 0.225 & 0.5 & 0.775 & 1.3 & 1.275 & 2.42 & 2.47 & 3.84 \\
\hline p.value(DML) & 0.043 & & 0.042 & & 0.045 & & 0.063 & \\
\hline p.value(amplit) & 0.043 & & 0.036 & & 0.036 & & 0.052 & \\
\hline
\end{tabular}

B)sensory nerve conduction: along the period of 3,6,9,12 months insignificant differences in the distal sensory latency

amplitude and conduction velocity ( $\mathrm{P} \geq 0.05$ )

Table (4). Sensory nerve conduction of the ulnar nerve in both groups.

\begin{tabular}{|c|c|c|c|c|c|c|c|c|}
\hline \multicolumn{9}{|c|}{ Ulnar nerve (7 patients) } \\
\hline & \multicolumn{2}{|c|}{3 months } & \multicolumn{2}{|c|}{6 months } & \multicolumn{2}{|c|}{9 months } & \multicolumn{2}{|c|}{12 MONTHS } \\
\hline & Gp.A & GpB & GpA & GpB & GpA & GpB & GpA & GpB \\
\hline \multicolumn{9}{|l|}{$(\mathrm{MEAN})$} \\
\hline $\mathrm{DML}(\mathrm{ms})$ & 7.4 & 6.43 & 5.95 & 5.86 & 5.38 & 4.47 & 4.72 & 3.96 \\
\hline Amplit.(mv) & 1.97 & 1.9 & 4.05 & 3.77 & 7.22 & 7.13 & 9.42 & 11.9 \\
\hline Velocity(ms) & 16 & 17.3 & 27 & 31.3 & 34.5 & 39 & 41 & 45 \\
\hline p.value(DML) & 0.235 & & 0.335 & & 0.442 & & 0.529 & \\
\hline p.value(amplit) & 0.152 & & 0.425 & & 0.438 & & 0.542 & \\
\hline p.value(velocity) & 0.235 & & 0.425 & & 0.357 & & 0.410 & \\
\hline
\end{tabular}

\subsubsection{Median Nerve}

results of sensory nerve conductions of the ulnar nerve.

As in ulnar nerve motor and sensory nerve conduction

Table (5). Motor nerve conductions of the Median nerve.

\begin{tabular}{|c|c|c|c|c|c|c|c|c|}
\hline \multicolumn{9}{|c|}{ Median nerve (11 patients) } \\
\hline & \multicolumn{2}{|c|}{3 months } & \multicolumn{2}{|c|}{6 months } & \multicolumn{2}{|c|}{9 months } & \multicolumn{2}{|c|}{12 MONTHS } \\
\hline & Gp.A & GpB & GpA & GpB & GpA & GpB & GpA & GpB \\
\hline \multicolumn{9}{|l|}{ (MEAN) } \\
\hline $\mathrm{DML}(\mathrm{ms})$ & 7.5 & 7.7 & 6.8 & 6.2 & 6.1 & 5.3 & 4.7 & 4.2 \\
\hline Amplit.(mv) & 0.1 & 0.5 & 2.6 & 3.41 & 3.3 & 4.5 & 4.4 & 5.2 \\
\hline p.value(DML) & 0.053 & & 0.042 & & 0.066 & & 0.051 & \\
\hline p.value(amplit) & 0.052 & & 0.053 & & 0.063 & & 0.047 & \\
\hline
\end{tabular}


Table (6). Sensory nerve conductions of the median nerves.

\begin{tabular}{|c|c|c|c|c|c|c|c|c|}
\hline \multicolumn{9}{|c|}{ Median nerve (11 patients) } \\
\hline & \multicolumn{2}{|c|}{3 months } & \multicolumn{2}{|c|}{6 months } & \multicolumn{2}{|c|}{9 months } & \multicolumn{2}{|c|}{12 MONTHS } \\
\hline & Gp.A & GpB & GpA & GpB & GpA & GpB & GpA & GpB \\
\hline \multicolumn{9}{|l|}{ (MEAN) } \\
\hline DML(ms) & 6.4 & 6.3 & 5.7 & 5.1 & 4.8 & 4.5 & 2.7 & 2.5 \\
\hline Amplit.(mv) & 5.2 & 5.3 & 8.72 & 9.25 & 16.1 & 17.4 & 28.4 & 30 \\
\hline Velocity(ms) & 15.5 & 17.2 & 24 & 25.5 & 31.8 & 32.8 & 41 & 42.32 \\
\hline p.value(DML) & 0.325 & & 0.226 & & 0.352 & & 0.541 & \\
\hline p.value(amplit) & 0.049 & & 0.635 & & 0.886 & & 0.514 & \\
\hline p.value(velocity) & 0.294 & & 0.103 & & 0.533 & & 0.541 & \\
\hline
\end{tabular}

\section{Discussion}

Spontaneous peripheral repair is unsatisfactory despite microsurgical intervention. Various technologies are used to augment the regenerative capacity of peripheral nerves (19). One of the most promising approaches is the use of cellular therapy as a potentiator repair. As Schwann cells play an important role in peripheral nerve regeneration, attempts to transplant Schwann cells have been exploited (20). However, this procedure is hampered by the invasive method of obtaining autologous Schwann cells.

Mesenchymal stem cells have been proven to transdifferentiate into Schwann-like cells $(21,22)$

Mode of action of MSC in neuroregeneration is diverse: promote endogenous neuronal growth, reduce apoptosis and down-regulate the inflammatory process through secreted factors. MSCs can also mediate modification of microenvironment enhancing endogenous neural regeneration. MSCs moreover induce survival and regeneration of neurons through secretion of trophic factors (23).

MSCs have been reported to be isolated from different sources. Since first described by Friedenstein et al from the bone marrow, they have been isolated from adipose tissue, peripheral blood, lungs and heart(24). Adipose-derived mesenchymal stem cells (ADSCs) express phenotypic and gene expression profiles similar to bone marrow derived MSCs (25). Moreover, they can be easily harvested with high frequency from subcutaneous fat, and show higher proliferative potential than bone marrow-derived MSCs (26, 27).

Gimble et al (2007) summarized the characteristics of ideal cells for regenerative application in the following criteria: can be harvested in abundant quantities using a minimally invasive procedure, can be differentiate into the required cell lineage in a reproducible method, and can be safely and effectively transplanted(28).

Adipose tissue stem cells can fulfill all these criteria. Adipose tissue can be collected in large amounts with minimal complications. ADSCs can be isolated from the collected lipoaspirate in relatively simple procedure, with no effect on cell viability.

ADSCs share the same biological characteristics of bone marrow derived MSCs with the superadded advantage of abundance and high proliferation(29).
In this study, we evaluated the role of ADSCs in enhancing peripheral nerve injury repair. Processing aspirated fat from $100-150 \mathrm{cc}$ fat produced ADSCs ranging from $1 \times 106$ to $3 \times 106$ which agrees with the results by other workers who reported that processing $300 \mathrm{ml}$ of lipoaspirate can yield from $1 \times 107$-to $6 \times 108$ ADSCs with $>90 \%$ viability (30).

In this study, the clinical and electrophysiolgical studies showed motor improvement in the stem cell group more than the conventional surgery group.

Stem cell group showed superior motor recovery in ulnar nerve after one year than the conventional group, with no difference in sensory recovery. In Median nerve injury, 40\% of the stem cell group reached normal strength compared to none in the traditional group, while $60 \%$ showed sensory recovery compared to $50 \%$ in traditional group These results agree with those of Kingham et al (31), Dezawa et al and Keihoff et al (32).

No complications were noticed after injection of ADSCs in nerve sheath. The procedure of liposuction and stem cell injection was well tolerated.

\section{Conclusion}

This pilot study proves the safety, and efficacy of using ADSCs to improve nerve repair in peripheral nerve injury. Thus stem cell therapy can be used safely as an adjuvant to surgical correction of peripheral nerve injuries. Further controlled trials should be performed using dose escalation to reach optimum therapeutic settings.

\section{References}

[1] Georgiou M, Golding JP,Loughlin AJ, Kingham PJ, Phillips J B (2015): Engineered neural tissue with aligned, differentiated adipose-derived stem cells promotes peripheral nerve regeneration across a critical sized defect in rat sciatic nerve. Biomaterials 37:242-251.

[2] Menorca RM, Fussell TS, Elfar JC. Nerve physiology: mechanisms of injury and recovery. Hand Clin.2013;29:317330 .

[3] Rodrigues MC, Rodrigues Jr. AA, Glover LE, Voltarelli J, Borlongan CV (2012): Peripheral nerve repair with cultured Schwann cells: getting closer to the clinics. Sc W J :413091. 
[4] Perrin FE, Lacroix M, Aviles-Trieueros M and David S (2005): Involvement of monocyte chemoattractant protein-1 macrophage inflammatory protein $1 \mathrm{a}$ and interleukin $1 \mathrm{~B}$ in Wallarian degeneration. Brain 128(4):854-866.

[5] Coleman MP and Freeman MR (2010): Wallarian degeneration, Wlds and Nmnat. An Rev Neurosc 33:245-267.

[6] Jiang L, Zhu JK, Liu L, Xiang P, Hu J, Yu WH (2008): Differentiation of rat adipose tissue-derived stem cells into Schwann-like cells in vitro. Neuroreport 19:1015-1019/

[7] Kaewkhaw R, Scutt AM, Haycock JW (2011): Anatomical site influences the differentiation of adipose-derived stem cells for Schwann-cell phenotype and function. Glia 59:734-749.

[8] Bertassoli BM, de Assis Neto AC, Oliveira FD, Arroyao M, Ferrao J, da Siva J, Pignatari G, Braga P (2013): Mesenchymal stem cells -emphasis in adipose tissue. Braz Arch. Biol Technol 56(4).

[9] Jiang L, Zhu JK, Liu XL, Xiang P, Hu J, Yu WH (2008): Differentiation of rat adipose tissue-derived stem cells into Schwann-like cells in vitro. Neuroreport 19:1015-1019.

[10] Kingham PJ, Kalbermaten DF, Mahay D, Armstrong SJ, Wiberg M, Terenghi G (2007): Adipose-derived stem cells differentiate into a Schwann cell phenotype and promote neurite outgrowth in vitro. Exp Neurol 207:267-274.

[11] Radtke C, Schmitz B, Spies M, Kocsis JD, Vogt PM (2009): Peripheral glial cell differentiation from neurospheres derived from adipose mesenchyal stem cells. Int J Dev Neurosci 27:817-823.

[12] Wudgerow AD, Salibian AA, Lalezari S, Evans GR (2013): Neuromodulatory nerve regeneration: adipose tissue-derived stem cells and neurotrophic mediation in peripheral nerve regeneration. J Neurosci Res 91:1517-1524.

[13] Kolar MK, Kingham PJ (2014): Regenerative effects of adipose-tissue-derived stem cells for treatment of peripheral nerve injuries. Biochem Soc Trans 42:697-701.

[14] Marconi S, Castiglione G, Turano E, Bissolotti G, Angiari S, Farinazzo (2012): Tissue Eng Part A 18:1264-1272.

[15] Reid AJ, Sun M, Wiberg M, Downes S, Terenghi G, Kingham PJ (2011): Nerve repair with adipose-derived stem cells protects dorsal root ganglia neurons from apoptosis. Neuroscience 199:515-522.

[16] Kingham PJ, Kolar MK, Novikova LN, Novikov LN, Wiberg $M$ (2014): Stimulating the neurotrophic and angiogenic properties of human adipose-derived stem cells enhances nerve repair. Stem Cells Dev, 23: 741-754.

[17] Zack-Wiliams S, Butler P, and Kalaskar D (2015): Current progress in use of adipose derived stem cells in peripheral nerve regeneration. W J Stem Cells 7(1):51-64.

[18] Mackinnon SE and Dellon AL (1988): Results of nerve repair and grafting. Surgery of the peripheral nerve Thieme 8 (4):110-115.

[19] Fairbairn NG, Meppelink AM, Ng-Glazier J, Randolph MA, Winograd JM (2015): Augmenting peripheral nerve regeneration using stem cells: A review of current opinion. W J Stem Cells 7(1):11-26.

[20] Whally K ( 2014): Schwann cells provide life support for axons. Nature Rev Neuroscience 15:689-699

[21] Faroni A, Rothwell SW, Grolla AA, Terenghi G, Magnaghi V and Verkhratsky A (2013): Differentiation of adipose derived stem cells into Schwann cell phenotype induced expression of $\mathrm{P} 2 \mathrm{X}$ receptors that control cell death. Cell Death and Disease 4:e743.

[22] Mantovani C, Terenghi G, Shawcross SG (2012): Isolation of adult stem cells and their differentiation to Schwann cells. Methods Mol Biol. 916:47-57.

[23] Joyce N, Annett G, Wirthlin L, Olson S, Bauer G and Nolta J (2010): Mesenchymal stem cells for the treatment of neurodegenerative disease. Regen Med 5(6):933-946.

[24] Hass R, Kasper C, Bohm S and Jacobs R (2011): Different populations and sources of sources of human mesenchymal stem cells (MSC): A comparison of adult and neonatal tissuederived MSC. Communication and Signaling 9:12.

[25] Strem BM, Hicok KC, Zhu M. (2005): Multipotential differentiation of adipose tissue-derived stem cells. Keio J Med. 54:132-41.

[26] Gimble JM, Katz AJ, Bunnell BA.(2007): Adipose-derived stem cells for regenerative medicine. Circ Res;100:1249-60.

[27] Liu G, Cheng Y, Feng Y, Pang C, Wang Y, Jia H and Tong X (2011): Adipose derived stem cells promote peripheral nerve repair. Arch Med Sci 7(4):592-596.

[28] Dong MM and Yi TH (2010): Stem cell and peripheral nerve injury and repair. Facial Plastic Surgery 26(5):4d21-427.

[29] Akita S, Akino K, Hirano A, Ohtsuru A and Yamashita S ( 2010): Mesenchymal stem cell therapy for cutaneous radiation syndrome. Health Phys 98(6):858-862.

[30] Boquest AC, Shahdadfar A, Brinchmann JE and Collas P (2006): Isolation of stromal stem cells from human adipose tissue. Methods Mol biol 325:35-46.

[31] Kingham PJ, Kalbermatten DF, Mahay D Armstrong SJ, Wiberg M, Terenghi (2007): Adipose-derived stem cells differentiate into a Schwann cell phenotype and promote neurite outgrowth in vitro. Exp Neurol 207:267-274.

[32] Keilhoff G, Stang F, Goihl A, Wolf G, Fansa H (2006): Transdifferentiated mesenchymal stem cells as alternative therapy in supporting nere regeneration and myelination. Cell Mol Neurobiol 26:1235-1252. 